\title{
Nauplius
}

The Journal of The

Brazilian Crustacean Society

\section{Distribution of the giant river prawn Macrobrachium rosenbergii (De Man, 1879) in Brazil: 43 years after its introduction}

e-ISSN 2358-2936

www.scielo.br/nau www.crustacea.org.br

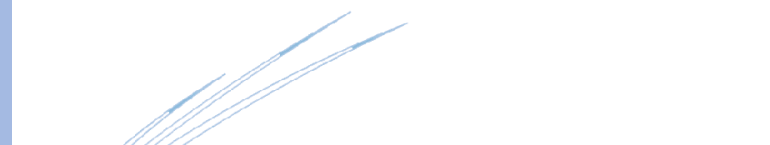

\begin{abstract}
Macrobrachium rosenbergii (De Man, 1879) is a freshwater prawn from Malaysia and in 1977 it was introduced in Brazil for development of carciniculture. However, this species is currently found in various natural environments in the Brazilian states. The present study aimed at conducting a survey of $M$. rosenbergii sites in the natural environment, and shrimp farming ponds using this species. To do so, a search was conducted in scientific articles and databases on the occurrence of the species in Brazil. We found reports in 80 different sites in Brazil. Macrobrachium rosenbergii was found in the natural environment in eight states and 43 cities, with the largest amount of reports being from the states of Pará and Maranhão. In addition, we found 28 reports in 13 states of shrimp farming ponds. Macrobrachium rosenbergii was not reported in natural environments in the Center-West region (except in state of Goiás) and North region (except in state of Pará). Moreover, we found that most of the $M$. rosenbergii reports were in temperature equal to or greater than $25^{\circ} \mathrm{C}$. Therefore, this species has expanded its area of occurrence throughout various Brazilian states, and we believe that this expansion may be greater than that reported in the current study.
\end{abstract}

\section{KeYWORDS}

Carciniculture, distribution expansion, exotic species, freshwater prawn

Corresponding Author Cicero Diogo Lins de Oliveira linsdiogoc@gmail.com

SUBMITTED 02 June 2020 ACCEPTED 21 September 2020 PUBLISHED 16 April 2021

DOI $10.1590 / 2358-2936 e 2021007$

\section{(cc) BY}

All content of the journal, except where identified, is licensed under a Creative Commons attribution-type BY.

Nauplius, 29: e2021007
Biological invasions are one of the main global threats to native biodiversity caused by humans (Walker and Stefen, 1997). Invasive species can compete directly with native species, reducing their populations and area of occurrence, and can lead to local extinction (Amaral et al., 2020). They can also cause destructive habitat change, and thus be harmful to nutrient cycling and the functioning of ecosystems (Masse et al., 2017).
Cicero Diogo Lins de Oliveira' (D) orcid.org/0000-0003-3779-023X

Lucia Vanessa Rocha Santos² (1) orcid.org/0000-0003-1616-6737

1 Universidade Federal de Alagoas, Maceió, Alagoas, Brazil.

2 Universidade Federal de Alagoas, Penedo, Alagoas, Brazil.

ZOOBANK: http://zoobank.org/urn:lsid:zoobank.org:pub:D7FB52A5-D013-4FA4B01E-E33608D96101 
These invasive species are present in various taxonomic groups and have distinct life strategies such as rapid growth, early maturation, high fecundity, high abundance among others (Sampaio and Valenti, 1996; Oliveira and Oliveira, 2019).

The number of non-native species in Brazil has exceeded 500 taxa, represented mainly by land animals (Coradin and Tortato, 2006). The principal vectors of exotic species introductions in aquatic environments are activities such as aquaculture, sport fishing, and the aquarium trade (Vitule and Prodocimo, 2012; Gubiani et al., 2018). These environments, especially lakes, lagoons, and reservoirs, are highly vulnerable to invasive species, mainly by crustaceans and fish (Karatayev et al., 2015; Gubiani et al., 2018). Among the non-native species cultivated in Brazil is the crustacean Macrobrachium rosenbergii (De Man, 1879), which has been introduced into at least 40 countries (FAO-DIAS, 2020).

Macrobrachium rosenbergii, known as the giant river prawn, which originated in Southeast Asia, has a longevity of approximately 3 years, and has been one of the most economically valued freshwater prawn species for aquaculture (Mitra et al., 2005; Brown et al., 2010) representing $3 \%$ of total global crustacean production in 2016 (FAO, 2018). The giant river prawn was introduced to Brazil in 1977 for cultivation experiments at the Department of Oceanography of the Federal University at Pernambuco, and as its cultivation improved, it has expanded to several Brazilian states (Cavalcanti, 1998; Mathias, 2005). However, due to the escape of specimens from these cultivation areas, the species is found in natural environments in some hydrographic basins in Brazil (Barros and Silva, 1997; Ibama, 1998) and has successfully colonized some locations (Cintra et al., 2003).

This success in natural environments is related to the high adaptivity of the species, which can survive in a wide range of salinity and temperature conditions due to its osmoregulatory adaptive mechanism (Barman et al., 2012). Therefore, the species has high tolerance and can adapt to different habitats and compete for habitat and food with native species such as Macrobrachium amazonicum (Heller, 1862) (Silva-Oliveira et al., 2011; Barbieri et al., 2016). These impacts still need to be better evaluated, because in addition to direct competition with native species, $M$. rosenbergii may carry pathogens, such as the white spot syndrome virus (WSSV), which in 2005 was responsible for an approximately $95 \%$ decrease in Brazilian production (Seiffert et al., 2005; Costa, 2010).

Therefore, it is necessary to know where the species is found to allow development of management plans for reducing its spread (Havel et al., 2015). In this context, we raised these questions: (I) What are the recorded locations of $M$. rosenbergii?; (II) In what types of environment is the species found (confined environments or free living)?; and (III) Is there a relationship between temperature and the presence of the species in Brazil?

To respond to the questions, we reviewed records about $M$. rosenbergii in Brazil, considering the type of occurrence, either in the natural environment or on farms, and relate this data with local temperatures. Research on the occurrence of $M$. rosenbergii in Brazil was conducted in databases of the Global Biodiversity Information Facility - GBIF (http://gbif.org) and the Horus Institute (http://bd.institutohorus.org. br/www/). Research from scientific articles and theses was also carried out on the Google Academics platform, using the keywords: "Macrobrachium rosenbergii AND Brasil OR Brazil”. From the articles found, we extracted the sites of occurrence, purchase of specimens, or sites of university experiments. In addition, data on regional mean annual temperature (1990-2010) were found on the WorldClim platform (https://www.worldclim.org/).

The occurrence data were classified into three categories: natural environment, when $M$. rosenbergii occurs in the environment; aquaculture, occurrence in aquaculture farms; and experiments (experimental cultivation). Subsequently, the frequency of the natural environment category and all the categories grouped by temperature classes, with intervals of $2^{\circ} \mathrm{C}$, was determined. Finally, qui-frame tests were performed, with a significance level of 0.05 (Zar, 2008), between the occurrences (natural environment) at high temperatures (equal or higher than $25^{\circ} \mathrm{C}$ ) and at temperatures below $25^{\circ} \mathrm{C}$.

Eighty different locations were found, of which one is registered in the GBIF platform, 30 in the Horus Institute, and 49 in scientific papers and web sites (Tab. S1). In the natural environment, $M$. rosenbergii was found in 43 municipalities and eight states: Pará, 
Maranhão, Piauí, Ceará, Sergipe, São Paulo, Rio de Janeiro and Paraná. In the cultivation sector there were 28 records distributed in 13 states: Ceará, Rio Grande do Norte, Paraíba, Pernambuco, Alagoas, Sergipe, Bahia, Goiás, Espirito Santos, Rio de Janeiro, São Paulo, Paraná, and Santa Catarina. The experiments were represented by 14 records, distributed in eight states: Rio Grande do Norte, Paraíba, Pernambuco, Rio de Janeiro, Minas Gerais, São Paulo, Paraná and Rio Grande do Sul (Fig. 1).

The state of Pará has the highest number of occurrences of $M$. rosenbergii in the natural environment (18 cases). São Paulo with five cities stands out for aquaculture, while for experimental occurrences, São Paulo and Paraná lead. The occurrence of $M$. rosenbergii in Brazil by temperature class, shows that they are grouped in the natural environment in temperature classes equal to or greater than $25^{\circ} \mathrm{C}$ (Fig. 2). When comparing the difference in the frequency of occurrence between less than $25^{\circ} \mathrm{C}$ and equal to or greater than $25^{\circ} \mathrm{C}$, we observed a significant difference in categories grouped $\left(x^{2}=4.34 ; p=0.048\right)$ and in the occurrence in natural environment $\left(x^{2}=32.36 ; p=0.001\right)$.

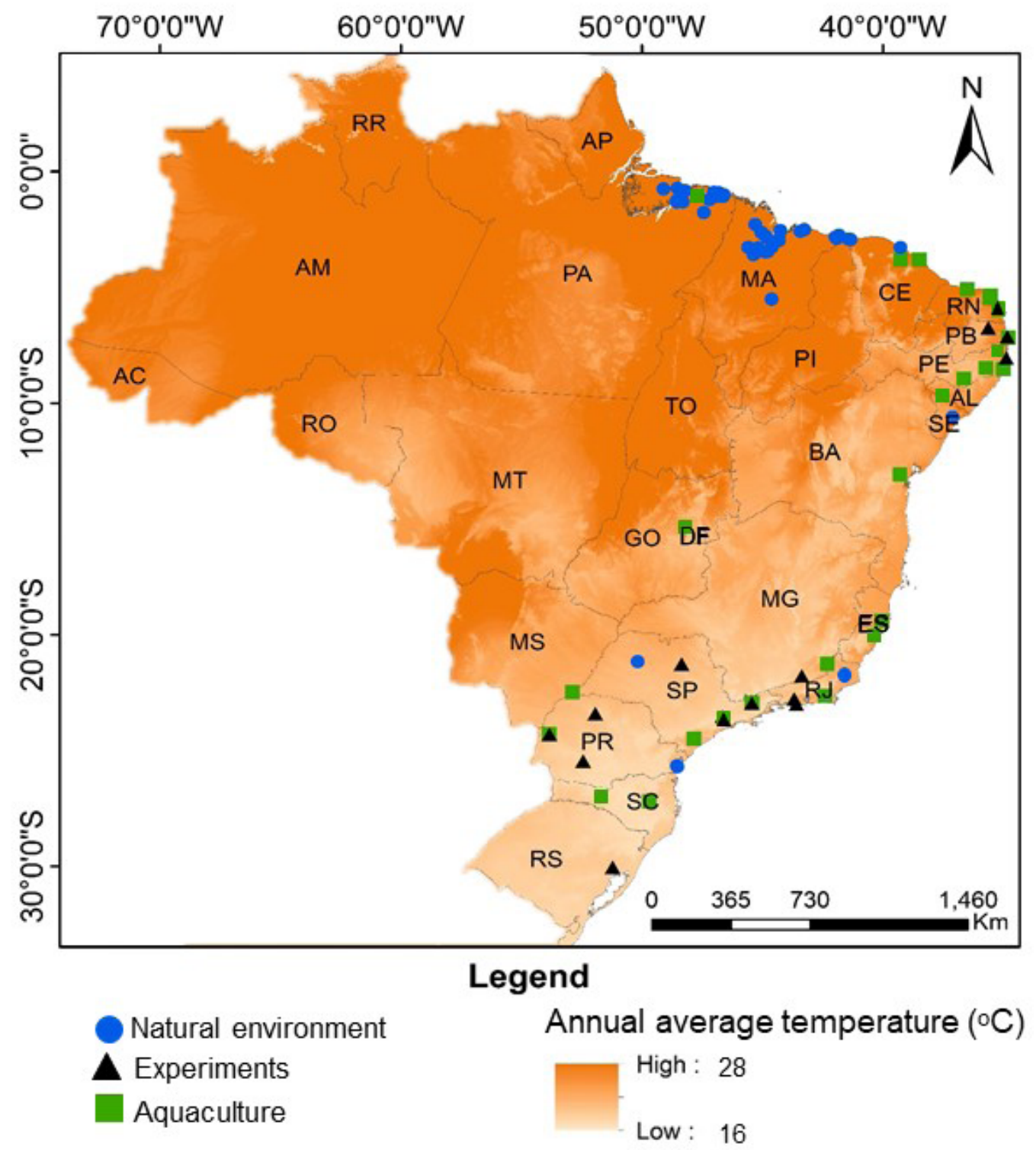

Figure 1. Occurrences of Macrobrachium rosenbergii in Brazil by state and temperature $\left({ }^{\circ} \mathrm{C}\right)$. $\mathrm{AC}$ - Acre; $\mathrm{AL}$ - $\mathrm{Alagoas} ; \mathrm{AP}$ - Amapá; AM - Amazonas; BA - Bahia; CE - Ceará; DF - Distrito Federal; ES - Espírito Santo; GO - Goiás; MA - Maranhão; MT - Mato Grosso; MS - Mato Grosso do Sul; MG - Minas Gerais; PA - Pará; PB - Paraíba; PR - Paraná; PE - Pernambuco; PI - Piauí; RJ - Rio de Janeiro; RN - Rio Grande do Norte; RS - Rio Grande do Sul; RO - Rondônia; RR - Roraima; SC - Santa Catarina; SP - São Paulo; SE - Sergipe; TO - Tocantins. 
Aquaculture in general has generated some negative impacts on the ambient environment, among these are the escape of non-native species (Barbieri et al., 2016; Côa et al., 2018; Gubiani et al., 2018). The giant river prawn is therefore a classic example of a species that has spread because of its popularity in commercial aquaculture (Iketani et al., 2011). In the same decade that it was brought to Brazil, the occurrence of the species was registered in natural watersheds (Barros and Silva, 1997; Ibama, 1998; Cintra et al., 2003). Later, new occurrences indicated that the species had spread rapidly, and was found in the states of Maranhão, Ceará, Pernambuco, Rio de Janeiro, São Paulo and Santa Catarina (Barros and Silva, 1997). Currently, 43 years after its introduction, it is found in eight states in the natural environment and 13 states under carciniculture. However, there is evidence that the number of states with $M$. rosenbergii farms is higher than we found (Marques and MoraesValenti, 2012), which may imply more occurrences in the natural environment and a broader distribution in Brazil, since its presence in these environments comes from aquaculture (Cintra et al., 2003).

The distribution of $M$. rosenbergii is associated with its capacity to adapt and establish itself in the environment, and its invasion is faster when it finds environmental characteristics similar to those at its origin (Moyle and Marchetti, 2006). Silva-Oliveira et al. (2011) reported that the region from Maranhão to the mouth of the Orinoco River in Venezuela has excellent characteristics for the species, when estimating the success of the species' colonization and dispersal in Brazil, mirroring the successful establishment of $M$. rosenbergii in Northern and Northeastern Brazil. This corroborates the large number of reports of its occurrence that we found in the states of Pará and Maranhão. Temperature contributes to the development and growth of water microbiota, and together with other physical and chemical factors of water, act directly on the composition and presence of necessary microorganisms (Silva et al., 2009). The giant river prawn has its highest growth at temperatures between 24 and $31^{\circ} \mathrm{C}$, with the optimal range being 28 to $30{ }^{\circ} \mathrm{C}$ (Valenti and New, 2000; New, 2002). Moreover, temperature also influences reproduction, since it is correlated with rainfall, thermal variations and photoperiod variation, which strongly influence the spawning period of $M$. rosenbergii (Pinheiro et al., 1998). This information corroborates the findings of this study, in which we observed that the species prefers regions with temperatures higher than $25^{\circ} \mathrm{C}$ (Fig. 2).

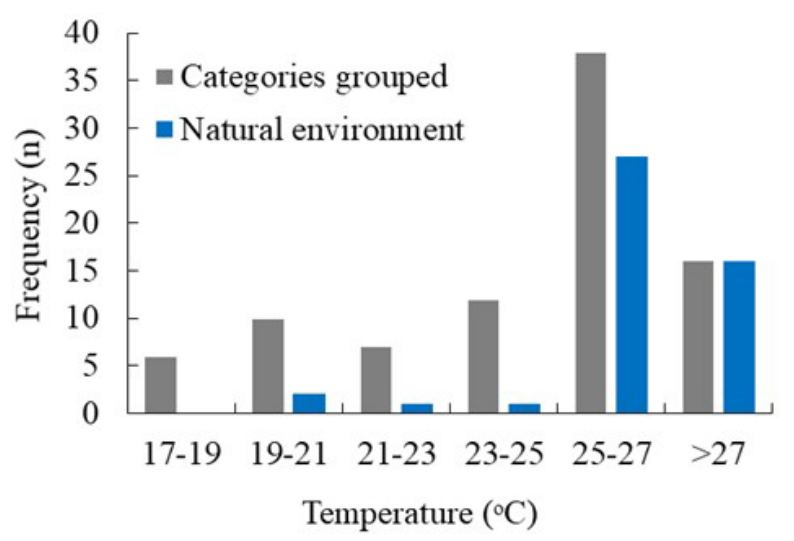

Figure 2. Frequency of Macrobrachium rosenbergii occurrences in Brazil by temperature class.

Salinity is also an essential factor for reproduction since most species of the genus Macrobrachium Spence Bate, 1868 need salinity gradient concentrations to complete their life cycle at each ontogenetic stage (Pinheiro et al., 1998; Ammar et al.2001). Cintra et al. (2003) and Iketani et al. (2016) registered ovigerous females of $M$. rosenbergii in natural environments in their studies in Pará, indicating that the species is established in the environment, and is able to complete its reproduction cycle. Therefore, the higher occurrence of the species in coastal regions is explained by its need for these brackish and high temperature waters for reproduction. These characteristics facilitate the successful colonization of M. rosenbergii (Silva et al., 2009; Silva-Oliveira et al., 2011), and this is probably the reason we found more reports of its occurrence closer to the coast, due to the species' need for salinity and high temperatures.

Under these circumstances, we can conclude that the species $M$. rosenbergii currently presents a wide distribution in several states and regions of Brazil and historical records point to aquaculture as a form of dispersal of the species between states. Aquaculture maintenance and monitoring failures have probably caused escape and introduction into the natural environment. The species has found favorable 
environments similar to its original environment and the data show it has adapted very well in Pará and Maranhão states due to high temperatures and probably because the introduction site is close to estuaries that have high salinity, allowing the species to complete its life cycle. The occurrence of $M$. rosenbergii in Brazil, mainly in natural habitats requires attention. This analysis suggests that studies of environmental monitoring and faunistic impact be conducted to understand the current situation of this introduction, and contribute to actions to control and prevent new escapes.

\section{ACKNOWLEDGMENTS}

We thank the Coordenação de Aperfeiçoamento de Pessoal de Nível Superior (CAPES), MSc. Carlos Yure Oliveira for his help in translation, and Jeffrey Hoff for grammar revision. Special thanks to the anonymous reviewers who contributed to the improvement of the article.

\section{Supplementary Material}

Table S1. Record of Macrobrachium rosenbergii in Brazil by classification and location. States: AL - Alagoas; BA - Bahia; CE - Ceará; ES - Espírito Santo; GO - Goiás; MA - Maranhão; MG - Minas Gerais; PA - Pará; PB - Paraíba; PE - Pernambuco; PI Piauí; PR - Paraná; RJ - Rio de Janeiro; RN - Rio.

\section{References}

Amaral, V.S.; Simone, L.R.L.; de Souza Tâmega, F.T.; Barbieri, E.; Calazans, S.H.; Coutinho, R. and Spotorno-Oliveira, P. 2020. New records of the non-indigenous oyster Saccostrea cucullata (Bivalvia: Ostreidae) from the southeast and south Brazilian coast. Regional Studies in Marine Science, 33: 100924.

Ammar, D.; Müller, Y.M.R. and Nazari, E.M. 2001. Biologia reprodutiva de Macrobrachium olfersii (Wiegman) (Crustacea, Decapoda, Palaemonidae) coletados na Ilha de Santa Catarina, Brasil. Revista brasileira de Zoologia, 2: 529-537.

Barbieri, E.; Coa, F. and Rezende, K.F.O. 2016. The exotic species Litopenaeus vannamei (Boone, 1931) occurrence in Cananeia, Iguape and Ilha Comprida lagoon estuary complex. Boletim do Instituto de Pesca, 42: 479-485.

Barman, H.K.; Patra, S.K.; Das, V.; Mohapatra, S.D.; Jayasankar, P.; Mohapatra, C.; Mohanta, R.; Panda, R.P. and Rath, S.N. 2012. Identification and characterization of differentially expressed transcripts in the gills of freshwater prawn (Macrobrachium rosenbergii) under salt stress. The Scientific World Journal, 2012: 1-11.
Barros, M.P. and Silva, L.M.A. 1997. Registro da introdução da espécie exótica Macrobrachium rosenbergii (De Man, 1879) (Crustacea, Decapoda, Palaemonidae), em águas do estado do Pará, Brasil. Boletim do Museu Paraense Emilio Goeldi. Série Zoologia, 13: 31-37.

Brown, J.H.; New, M.B. and Ismael, D. 2010. Biology. p. 18-39. In: M.B. New; W.C. Valenti; J.H. Tidwell; L.R. D’abramo and M.N. Kutty (eds), Freshwater Prawns: Biology and Farming, Wiley-Blackwell, Chichester.

Cavalcanti, L.B. 1998. Histórico. p. 17-20. In: W.C. Valenti (ed), Carcinicultura de Água Doce. Instituto Brasileiro do Meio Ambiente e do Recursos Naturais Renováveis, Brasília.

Cintra, I.H.A.; Silva, K.C.A. and Muniz, A.P.M. 2003. Ocorrência de Macrobrachium rosenbergii (de Man, 1879) em Áreas Estuarinas do Estado do Pará (Crustacea, Decapoda, Palaemonidae). Boletim Técnico Científico do CEPNOR, 3: 219-227.

Côa, F.; de Medeiros, A.M.Z. and Barbieri, E. 2018. Registro da tilápia-do-nilo no Rio Mandira, Cananéia, Estado de São Paulo. Boletim do Instituto de Pesca, 43: 87-91.

Coradin, L. and Tortato, D.T. 2006. Espécies exóticas invasoras: situação brasileira. Brasília, Ministério do Meio Ambiente, Secretaria de Biodiversidade e Florestas, 24p.

Costa, S.W. 2010. Aquicultura no Estado de Santa Catarina: situação atual e perspectivas. Revista da ABCC, 12: 49-50.

FAO. 2018. El estado mundial de la pesca y la acuicultura. Cumplir los objetivos de desarrollo sostenible. Food and Agriculture Organization, Organización de las Naciones Unidas para la Alimentación y la Agricultura, Roma, 2018, 233p.

FAO-DIAS. 2020. Food and Agriculture Organization of the United Nations, Database on Introductions of Aquatic Species (FAO-DIAS). Available at http://www.fao.org/fishery/dias/ en. Accessed on 7 March 2020.

Gubiani, E.A.; Ruaro, R.; Ribeiro, V.R.; Eichelberger, A.C.A.; Bogoni, R.F.; Lira, A.D.; Cavalli, D.; Piana, P.A. and da Graca, W.J. 2018. Non-native fish species in Neotropical freshwaters: how did they arrive, and where did they come from? Hydrobiologia, 817: 57-69.

Havel, J.E.; Kovalenko, K.E.; Thomaz, S.M.; Amalfitano, S. and Kats, L.B. 2015. Aquatic invasive species: challenges for the future. Hydrobiologia, 750: 147-170.

IBAMA. 1998. PORTARIA no 145/98, de 29 de outubro de 1998. Brasília, Instituto Brasileiro do Meio Ambiente e dos Recursos Naturais Renováveis - IBAMA, 10 p.

Iketani, G.; Aviz, M.A.B.; Maciel, C.; Valenti, W.; Schneider, H. and Sampaio, I. 2016. Successful invasion of the Amazon Coast by the giant river prawn, Macrobrachium rosenbergii: evidence of a reproductively viable population. Aquatic Invasions, 11: 277-286.

Iketani, G.; Pimentel, L.; Silva-Oliveira, G.; Maciel, C.; Valenti, W.; Schneider, H. and Sampaio, I. 2011. The history of the introduction of the giant river prawn, Macrobrachium cf. rosenbergii (Decapoda, Palaemonidae), in Brazil: New insights from molecular data. Genetics and Molecular Biology, 34: $142-151$.

Karatayev, A.Y.; Burlakova, L.E. and Padilla, D.K. 2015. Zebra versus quagga mussels: a review of their spread, population dynamics, and ecosystem impacts. Hydrobiologia, 746: 97112. 
Marques, H.L.A. and Moraes-Valenti, P.M. 2012. Current status and prospects of farming the giant river prawn (Macrobrachium rosenbergii (De Man, 1879)) and the Amazon river prawn (Macrobrachium amazonicum (Heller, 1862)) in Brazil. Aquaculture Research, 43: 984-992.

Masse, P.S.; Tindo, M.; Kenne, M.; Tadu, Z.; Mony, R. and DjiétoLordon, C. 2017. Impact of the invasive ant Wasmannia auropunctata (Formicidae: Myrmicinae) on local ant diversity in southern Cameroon. African Journal of Ecology, 55: 423-432.

Mathias, M.A.C. 2005. Macrobrachium rosenbergii: um "gigante" ainda adormecido. Panorama da Aquicultura, 96: 60-60.

Mitra, G.; Mukhopadhyay, P.K. and Chattopadhyay, D.N. 2005. Nutrition and feeding in freshwater prawn (Macrobrachium rosenbergii) farming. Aqua Feeds: Formulation and Beyond, 2: $17-19$.

Moyle, P.B. and Marchetti, M.P. 2006. Predicting invasion success: freshwater fishes in California as a model. BioScience, 56: 515-524.

New, M.B. 2002. Farming freshwater prawns: a manual for the culture of the giant river prawn (Macrobrachium rosenbergii) (No. 428). Food and Agriculture Org., 212p.

Oliveira, C.D.L. and Oliveira, C.Y.B. 2019. Growth parameters of the invasive gastropod Melanoides tuberculata (Müller, 1774) (Gastropoda, Thiaridae) in a semi-arid region, Northeastern Brazil. Acta Scientiarum. Biological Sciences, 41: e45720.

Pinheiro, M.A.A. and Hebling, N.J. 1998. Biologia de Macrobrachium rosenbergii (De Man, 1879). p. 21-46. In: W.C. Valenti (ed), Carcinicultura de água doce. Tecnologia para produção de camarões. Brasília, Instituto Brasileiro de Meio Ambiente e dos Recursos Naturais Renováveis.

Sampaio, C.M. and Valenti, W.C. 1996. Growth curves for Macrobrachium rosenbergii in semi-intensive culture in Brazil. Journal of the World Aquaculture Society, 27: 353-358.

Seiffert, W.; Costa, S.W. and Maggioni, D. 2005. A mancha-branca em Santa Catarina. Revista Panorama da Aquicultura, 15: 51-53.

Silva, G.M.F.; Pantoja Ferreira, M.A.; Von Ledebur, E.I.C.F. and Da Rocha, R.M. 2009. Gonadal structure analysis of Macrobrachium amazonicum (Heller, 1862) from a wild population: a new insight into the morphotype characterization. Aquaculture Research, 40: 798-803.

Silva-Oliveira, G.C.; Ready, J.S.; Iketani, G.; Bastos, S.; Gomes, G.; Sampaio, I. and Maciel, C. 2011. The invasive status of Macrobrachium rosenbergii (De Man, 1879) in Northern Brazil, with an estimation of areas at risk globally. Aquatic Invasions, 6: 319-328.

Valenti, W.C. and New, M.B. 2000. Freshwater prawn culture: the farming of Macrobrachium rosenbergii. Oxford, Blackwell Scientific, 443p.

Vitule, J.R.S. and Prodocimo, V. 2012. Introdução de espécies não nativas e invasões biológicas. Estudos de Biologia, 34: 225-237.

Walker, B. and Steffen, W. 1997. An overview of the implications of global change for natural and managed terrestrial ecosystems. Conservation ecology, 1: 1-17.

Zar, J.H. 2008. Biostatistical analysis, 5th ed. New York, Prentice Hall, 610p. 